\title{
Films and Science: quantification and analysis of the use of Science Fiction films in scientific papers
}

\section{Luciano Guillermo Levin and Daniela De Filippo}

\begin{abstract}
The purpose of this study is to quantify the use of science fiction films in academic papers as well as to analyse the patterns of use of those films indexed in international databases, using the ISI Web of Science database. Twenty films were selected from recognised sources. Films referenced in the scientific literature were detected and, with quantitative methodologies, we classified their genres, the journals of publication and the disciplines they belong to. Finally, we performed a detailed study of each paper in which selected films were found, to observe and categorise specifically the ways such film references are used.
\end{abstract}

KEYWORDS: Science fiction, science communication, science and cinema

\section{Introduction}

Currently, there is a significant bibliographic corpus dealing with the mutual relations between science and cinema in the course of their development [7, 11, 13, 16, 19, 25].

Those works have demonstrated, for example, the role played by filmmakers in the development of various technologies $[10,13,20]$ and the influence of cinema on education, only to mention two subjects frequently dealt with. On the other hand, the representation of the work carried out by scientists in fictional cinematographic productions has provided them with a certain legitimacy within the academia as well as in the eyes of public opinion [12]. Additionally, the proliferation of international science film festivals has caused the two worlds usually classified with the label "Films \& Science" to draw even closer.

As a result, although not the standard yet, film references have begun to play an increasingly relevant role in the arguments of academic papers and in this type of literature in general. The aim of our study is to analyse the reasons why academic literature uses this sort of quotations.

In order to approach the issue, we have selected a segment of the cinematographic world that is particularly relevant: sci-fi films. This solution meets three requirements. Firstly, these films evidently have to convince the audience that a certain type of scientific world view is possible $[14,23,25]$. Secondly, it is a vast cinematographic segment that has a very strong influence on culture and society. Finally, sci-fi cinema probably is the oldest film genre. 
As only little is known about the quantity of texts that use cinema in their arguments, part of the study was carried out through quantitative methods aiming to calculate the number of academic papers mentioning one or more sci-fi films in their arguments or explanations. Using bibliometric methods, we found out the films that have originated the largest number of publications, the text genres that are used, the journals the papers are published in and the subjects they deal with.

Our focus is on defining typologies that shed light on the specific ways of using these films. To this purpose, a detailed analysis will be performed on the content of all the documents mentioning any of the selected films.

\section{Methodology}

\subsection{Definitions}

Science Fiction: science fiction is characterised by cognitive estrangement [23]. Estrangement is a process used by fiction in general, which creates a dialectic relationship between the rules governing the fictional world and the alteration of such rules. This process draws us into an apparent normality, in which we become involved as the plot of the story develops. In science fiction, the rules that are established and altered are specifically the rules of the cognitive laws that we have developed to explain the world, i.e. science.

Journals: for this study, we exclusively worked with academic journals that publish research papers subject to peer review, which comply with rigorous quality standards and are exclusively addressed to an academic audience. Regardless of their subject, all the papers analysed belong to this group of publications. We did not work with general science popularisation articles. In order to make sure we chose this type of publications, we consulted world-renowned international multidisciplinary databases that index the main scientific mainstream journals, such as the Thomson Reuters Web of Science (WoS).

\subsection{Selection of films}

The first step was shortlisting a number of highly significant films ranging from older scifi cinema classics - such as Metropolis, Frankenstein or The Invisible Man - to the most recent ones, such as Minority Report, Inception o Avatar. We consulted lists of science fiction films whose prestige, recognition and diffusion have made them indispensable for anyone who wants to speak of this genre. ${ }^{1}$ We selected films released before $1^{\text {st }}$ January 2012. Based on these criteria, a list of 20 films was drawn up (presented in Table 1).

\footnotetext{
${ }^{1}$ List of science fiction films by the Michigan University: http://www.umich.edu//umfandsf/film/films/; top science fiction films by the American Film Institute (AFI): http://www.afi.com/10top10/category. aspx?cat=7; list of science fiction films on Wikipedia: http://es.wikipedia.org/wiki/Anexo:Películas_de_ ciencia_ficción; list of science fiction films on the Internet Movie Data base (IMDB): www.imdb.com
} 
Table 1. Sci-fi films selected.

\begin{tabular}{|c|c|c|c|}
\hline $\begin{array}{l}\text { Film } \\
2001 \text { A Space Odyssey }\end{array}$ & $\begin{array}{l}\text { Year } \\
1968\end{array}$ & $\begin{array}{l}\text { Film } \\
\text { GATTACA }\end{array}$ & $\begin{array}{l}\text { Year } \\
1997\end{array}$ \\
\hline The 6th day & 2000 & The Invisible Man & 1933 \\
\hline A Clockwork Orange & 1971 & Jurassic Park & 1993 \\
\hline Alien & 1979 & Matrix & 1999 \\
\hline The Andromeda Strain & 1971 & Metrópolis & 1927 \\
\hline Avatar & 2010 & Minority Report & 2002 \\
\hline The Bicentennial man & 1999 & Inception & 2010 \\
\hline Blade Runner & 1982 & Planet of the Apes & 1968 \\
\hline Brazil & 1985 & Solaris & 1972 \\
\hline Frankenstein & 1931 & Terminator & 1984 \\
\hline
\end{tabular}

\subsection{Selection of sources and procedures}

\subsubsection{Web of Science publications}

The main goal of the first phase of the study was to quantify and analyse the bibliographic corpus of papers that make a reference to the shortlisted science fiction films within the Web of Science ${ }^{2}$ (WoS) scientific literature. To this purpose, researched the title and the director of the films in the "Topics" (TS) field, which looks for hits in the title, abstract and key words of each publication.

After detecting and downloading the selected records, an analysis of their formal characteristics was carried out, including document genre, language, main subject and journal in which they are published. A further content analysis was made to quantify the references to the film in the titles and in the abstracts and to subsequently draw up a range of categories to identify the reason for the reference.

\subsubsection{BioOne, Cell, PUS and SSS publications}

On the basis of the journals indexed in Web of Science, we selected a group of journals to carry out an analysis of the full paper texts. As the focus of our study was the influence of cinema on science, we decided to explore papers in which the film reference

\footnotetext{
${ }^{2}$ In this case, we considered the three databases included in WoS: Science Citation Index (SCI) - 1900 to present, it provides bibliographic information and references in the field of science from approximately 6,125 journals and also includes 145 of the most quoted books; Social Science Citation Index (SSCI) 1956 to present, it provides bibliographic information and references in the field of social science from about 1,810 journals and 30 of the most quoted books; Arts and Humanities Citation Index (A\&HCI) 1975 to present, it provides bibliographic information and references in the field of arts and humanities from approximately 1,130 journals and 15 series of the most quoted books.
} 
does not have a descriptive character. To this purpose, we left out the papers that exclusively review the films or analyse their subjects, despite the fact that they are published in academic journals.

Therefore we selected the most significant journals dealing with biological science and social science aiming to study two distinct areas that comply with very different quality and writing style criteria.

As concerns biology journals, we found out that papers on the selected films were published in Cell and Bioscience. The journal Cell belongs to the publishing house of the same name, which brings together 30 biology journals. On the other hand, the journal BioScience belongs to the publisher BioOne, which groups over 170 journals. In order to widen the range of journals and based on the fact that a single publisher follows the same line for all of its publications, we decided to analyse all the journals from both publishers.

On the other hand, the social science journals that generated results on the shortlisted films were Social Studies of Science (SSS) and Public Understanding of Science (PUS). In this case, we decided to analyse them as PUS is the most prestigious science journal within the science communication field with over 20 years of history, whereas SSS is the main science journal within social studies on science and technology. In addition, both of them are renowned references in the area of science history and philosophy, ranking among the three most significant journals in the Social Science Citation Index by Thomson Reuters.

The goal of this phase of the study was to identify the ways sci-fi films are used. To this purpose, we analysed the full texts of all the papers mentioning the shortlisted films in the four journals selected. The first selection was carried out through an automatic search.

Subsequently, we read the texts and removed those not referring to the films by categorising the papers by document type and subject. In the analysis of the content, the following variables were created in order to collect information allowing us to identify the specific way in which a film is used in a paper:

i. Location in the text: we noted down if the film reference appears in the abstract, in the introduction, in the body of the paper, or in its conclusions.

ii. How many references are made: we counted how many times the film is mentioned in each of the papers.

iii. References to other films: we recorded whether there is only a film being referred in the text or the reference is made in a context including other films.

iv. Who mentions the film?: we recorded whether the film was referred to by the author or by an interviewee or even a third-party source, for example quotations from other articles, etc.

v. Purpose of the film reference: we analysed the goal of the film reference: to exemplify, to compare, to put forward a theory.

vi. The existence of a formal method to mention the films: we analysed how the film is mentioned to establish whether there is a standardisation of film references. 
Table 2. Number of Web of Science publications on sci-fi films.

\begin{tabular}{|l|c|}
\hline Films & No. \\
\hline 2001 A Space Odyssey & 26 \\
\hline 6th day & 0 \\
\hline A clockwork orange & 3 \\
\hline Alien & 2 \\
\hline The Andromeda Strain & 6 \\
\hline Avatar & 10 \\
\hline Bicentennial man & 3 \\
\hline Blade Runner & 0 \\
\hline Brazil & 2 \\
\hline Frankenstein & 4 \\
\hline
\end{tabular}

\begin{tabular}{|l|c|}
\hline Films & No. \\
\hline GATTACA & 1 \\
\hline Inception & 0 \\
\hline The Invisible Man & 0 \\
\hline Jurassic Park & 9 \\
\hline Matrix & 2 \\
\hline Metrópolis & 7 \\
\hline Minority Report & 5 \\
\hline Planet of the Apes & 8 \\
\hline Solaris & 3 \\
\hline Terminator & 2 \\
\hline
\end{tabular}

\section{Results}

\subsection{Quantification in Web of Science (Abstracts, titles and keywords)}

The search in the corpus of the academic journals (excluding those dealing with cinema and cultural studies) yielded 93 papers. Out of that figure, 2001: A Space Odyssey was referred to in a total of 26 publications, followed by Avatar (10); Jurassic Park (9); Planet of the Apes (8) and Metropolis (7) (Table 2).

Although it is conceivable that older films are more likely to obtain references, no relationship between the year of release and the number of publications was noted. This is because films are not "built-up knowledge pieces" like papers. In fact, a recent film is much more likely to be referenced than an old film, as the involved representations of science and knowledge will be more useful and closer to the experience of scientists and their readers than the knowledge depicted in an old film. This is why Avatar - the most recent of the films considered in the study — is featured in a considerable number of publications. In this regard, it can be noted that the highest number of papers on sci-fi films was published in the past decade.

A few formal characteristics of the publications, such as the language, the genre of text, the subject or the journal, are relevant as a basis for a first categorisation. In general terms, it can be noted that the 93 papers gathered were written in English and "article" is their main genre (55\%), followed by "proceeding paper" (14\%). As for the subjects, the 20 films analysed were especially taken from journals in the field of "humanities" (17\%), followed by "history" and "aerospace engineering" (6\% each) (Figure 1). ${ }^{3}$

By reading the 93 records found (titles and abstracts) one time, it was possible to note that in 57 papers $(61 \%)$ the reference to the films is only made in the title. In other cases,

\footnotetext{
${ }^{3} \mathrm{~A}$ full list of the journals that yielded results is presented in the appendix.
} 


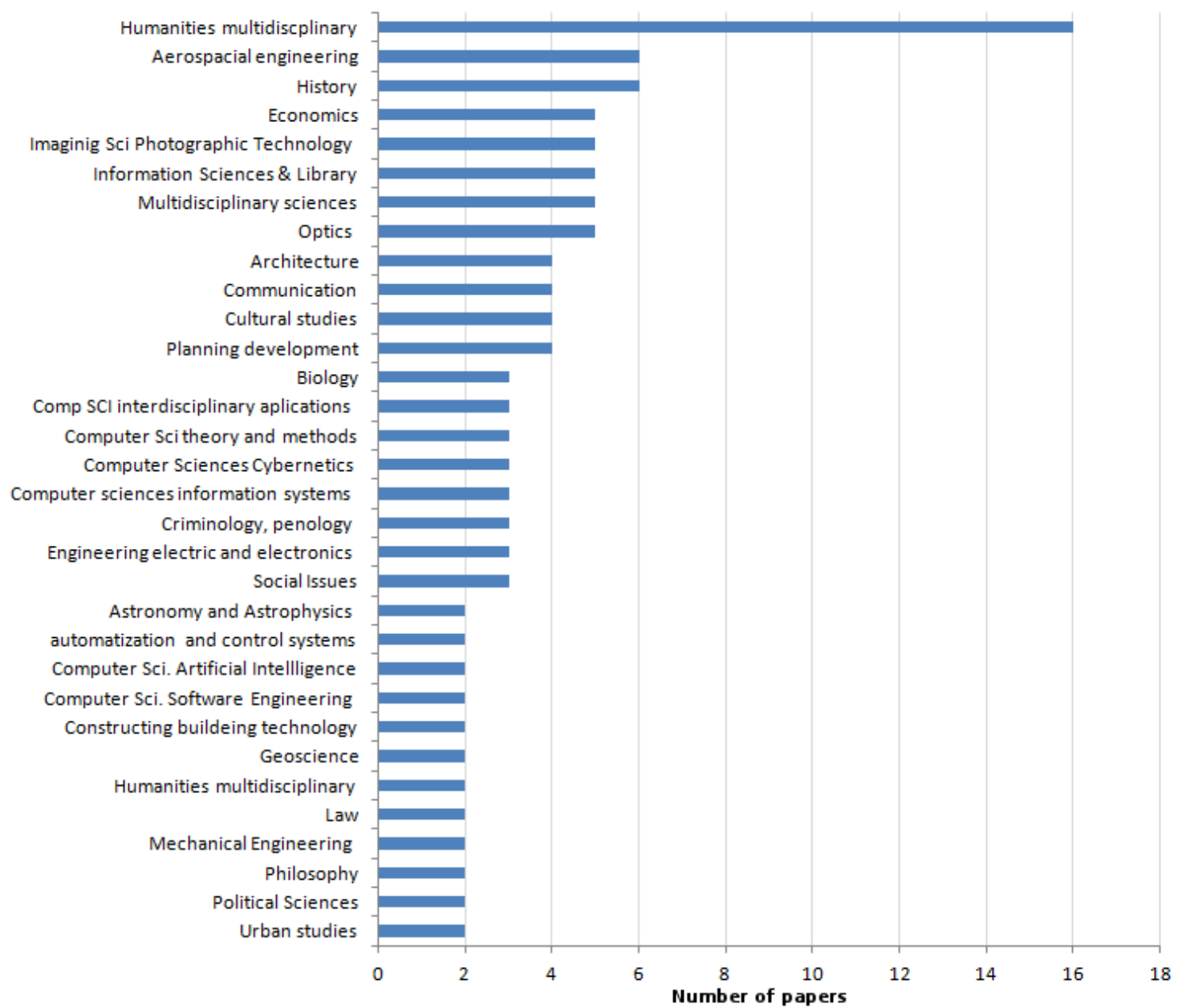

Figure 1. Distribution of publications on sci-fi films by subject $(<1 \mathrm{doc})$.

when the film is brought as an example for social analysis or used to allude to the positive or negative effects of science and technology, it is possible to detect a more frequent use of metaphors and stylistic devices.

The different usage patterns detected in titles and abstracts allow for the creation of categories for the analysis of the content. In this regard, it was possible to identify four main reasons why a film is included in a paper:

- Publications focusing on the film as a study subject without being descriptive, but which analyse some specific aspect of it.

E.g. (Abstract)

"Classical science fiction films have been depicting space voyages, aliens, trips to the moon, the sun, Mars, and other planets, known and unknown. While it is difficult to critique the depiction of fantastic places, or planets about which little was known at the time, the situation is different for the moon, about which 
a lot of facts were known from astronomical observations even at the turn of the century. Here we discuss the grade of realism with which the lunar surface has been depicted in a number of movies, beginning with George Méliés' 1902 classic Le Voyage dans la lune and ending, just before the first manned landing on the moon, with Stanley Kubrick's 2001: A Space Odyssey." [8]

- Papers focusing on the analysis of the medium or format (3D, IMAX, sound, etc.), having both a descriptive and analytical nature with regard to the consequences of these formats on the spectators.

E.g. (Abstract)

"As the flat panel displays (Liquid Crystal Displays, AMOLED, etc.) reach near perfection in their viewing qualities and display areas, it is natural to seek the next level of displays, including 3D displays. There is a strong surge in 3D liquid crystal displays as a result of the successful movie Avatar." [26]

- Papers analysing the relation between sci-fi cinema and society. They are primarily papers studying the way cinema depicts or foresees reality by presenting arguments in favour or against scientific and technological development (bioethics, ecology, urban development, etc.) or by analysing different stereotypes (scientists, laboratories, etc.). This type of papers can be featured in journals dealing with social science as well as biological and experimental science.

E.g. (Title)

"Apocalyptic Imagery in Fritz Lang's Metropolis" [4]

- Papers in which films are used to represent or exemplify specific scientific or technological developments. They are usually found in experimental or biomedical science journals.

E.g. (Title)

"Ebola virus and hemorrhagic-fever Andromeda Strain or localised pathogen" [9]

Table 3 shows the total number of papers that can be included in each of the categories detailed above. In particular, category a) appears to be the largest one, which is logical as the reference to the name of a film in the title or abstract reveals that it is a focus of the text. However, it is interesting to note also the importance of the analysis of the technologies that are part of the technical means of sci-fi films, which has been a particularly relevant subject in papers on the most recent films.

Within category a), an important role is played by the papers that analyse different forms of representing issues related to science: scientists, representations of astronomical objects (like the Moon) or of certain technologies (robots or computers).

Category b) is comprised of the papers that deal with the social aspects of films. The subjects are so diverse that it is nearly impossible to subcategorise them. However, an important role is played by the presence of criminology aspects in the application of new technologies. The papers also contain political analysis, the representation of neurobiological concepts, the study of predictive elements in cinema, environmental analysis and urban studies, etc. 
Table 3. Number of papers by reason for the film reference.

\begin{tabular}{|l|c|c|}
\hline Reason for film reference & $\begin{array}{c}\text { Number of } \\
\text { papers }\end{array}$ & $\mathbf{\%}$ \\
\hline a) Film as a study subject & 51 & 55 \\
\hline c) Relation between science fiction and society & 18 & 19 \\
\hline d) Example of scientific/technological developments & 15 & 16 \\
\hline b) Study on the medium or format & 9 & 10 \\
\hline Total papers & $\mathbf{9 3}$ & $\mathbf{1 0 0}$ \\
\hline
\end{tabular}

In the papers studying technological developments (c), the most common issues were the design of spacecrafts and the biological technologies for euthanasia.

Finally, the majority of papers dealing with the technical aspects of films (d) analyse the application of new technologies to pictures, such as the digitalisation of complex scenery and 3D technologies.

\subsection{Analysis of the use in BioOne, Cell, PUS and SSS (full text)}

As in the previous phase, advanced search methods were applied to the databases using the name of the film and of the director, and then the terms were restricted to avoid ambiguities. The search yielded 108 papers, whose characteristics were analysed.

The results show that Jurassic Park was the most popular film in this selection of journals, being mentioned in more than half of the papers appeared in results. Other popular films were GATTACA with 16 papers and 2001: A Space Odyssey or The Andromeda Strain with 6 papers each (Table 4).

The article is the prevailing genre, with $71 \%$ of the papers, followed by the book review with $11 \%$. Articles are highly relevant with Jurassic Park and GATTACA, as they represent $75 \%$ of the papers.

The analysis of the full text allowed us to learn about a few general aspects and note that most film references appear in the body of the text, while only $2.5 \%$ appear in the title, a negligible percentage in the abstract, which is interesting to make comparisons with the data collected in the first step of this work, in which all the papers were consistent with the findings in these two positions. In addition, it was possible to demonstrate that in $30 \%$ of cases when a reference is made to a film, the paper also contains references to other films. In almost all cases, the film reference is introduced in the text by the author (97\%) and usually there is not a formal film citation style, as there is standardisation in only $4 \%$ of the papers. Almost $70 \%$ of the papers mention the selected film only once. A much smaller percentage of papers mention the film less than 5 times and only a few papers mention the films more times. This information is shown in Table 5. 
Table 4. Number of papers referring to selected films, for each source.

\begin{tabular}{|l|r|r|r|r|r|}
\hline \multirow{2}{*}{ Film } & \multicolumn{5}{|c|}{ Number of papers } \\
\cline { 2 - 6 } & BioOne & Cell & PUS & SSS & Total \\
\hline 2001 A Space Odyssey & 1 & 2 & 1 & 2 & $\mathbf{6}$ \\
\hline The 6th day & 0 & 0 & 0 & 0 & $\mathbf{0}$ \\
\hline A clockwork orange & 1 & 0 & 0 & 0 & $\mathbf{1}$ \\
\hline Alien & 0 & 2 & 0 & 0 & $\mathbf{2}$ \\
\hline The Andromeda Strain & 0 & 3 & 3 & 0 & $\mathbf{6}$ \\
\hline Avatar & 0 & 1 & 0 & 0 & $\mathbf{1}$ \\
\hline Bicentennial man & 0 & 0 & 0 & 0 & $\mathbf{0}$ \\
\hline Blade Runner & 1 & 1 & 3 & 0 & $\mathbf{5}$ \\
\hline Brazil & 0 & 0 & 0 & 0 & $\mathbf{0}$ \\
\hline Frankenstein & 0 & 0 & 4 & 0 & $\mathbf{4}$ \\
\hline GATTACA & 6 & 2 & 7 & 1 & $\mathbf{1 6}$ \\
\hline Inception & 0 & 0 & 0 & 0 & $\mathbf{0}$ \\
\hline The Invisible Man & 0 & 0 & 1 & 0 & $\mathbf{1}$ \\
\hline Jurassic Park & 18 & 17 & 18 & 2 & $\mathbf{5 5}$ \\
\hline Matrix & 1 & 0 & 0 & 0 & $\mathbf{1}$ \\
\hline Metropolis & 0 & 1 & 1 & 1 & $\mathbf{3}$ \\
\hline Minority Report & 0 & 0 & 1 & 0 & $\mathbf{1}$ \\
\hline Planet of the Apes & 1 & 1 & 2 & 1 & $\mathbf{5}$ \\
\hline Solaris & 24 & 13 & 0 & 0 & $\mathbf{0}$ \\
\hline Terminator & 0 & 0 & 1 & 0 & $\mathbf{1}$ \\
\hline Total & $\mathbf{9 9}$ & $\mathbf{5 9}$ & $\mathbf{4 8}$ & $\mathbf{1 0}$ & $\mathbf{1 0 8}$ \\
\hline
\end{tabular}

In order to analyse the purpose of the film reference, it was necessary to categorise this variable (purpose of the reference, see Figure 2). The various categories were established after reading the full text of the papers. Similarly to the categories created for the abstracts from the Web of Science journals, also here we propose a series of categories for the type of use. Here the reference is much more specific and its categorisation is more detailed:

- Educational instrument: it refers to the use of a film in a formal educational context, both as part of an educational strategy and as a resource in itself.

E.g.

"I first piloted this idea with an original podcast entitled "Cloning Extinct Species: Fact or Science Fiction" that described the cloning methods and 
Table 5. Main results by variables of use.

\begin{tabular}{|l|l|r|}
\hline Variable & Indicator & \# references \\
\hline \multirow{4}{*}{ Location } & Title & 6 \\
\cline { 2 - 3 } & Abstract & 2 \\
\cline { 2 - 3 } & Key words & 0 \\
\cline { 2 - 3 } & Introduction & 3 \\
\cline { 2 - 3 } & Body & 200 \\
\cline { 2 - 3 } & Conclusions & 10 \\
\cline { 2 - 3 } & Bibliography & 5 \\
\cline { 2 - 3 } & Other & 10 \\
\hline
\end{tabular}

\begin{tabular}{|c|c|c|}
\hline Variable & Indicator & \# references \\
\hline \multirow{4}{*}{ Frequency } & 1 & 75 \\
\hline & 2 a 5 & 18 \\
\hline & 6 a 10 & 3 \\
\hline & over 10 & 4 \\
\hline \multirow{2}{*}{$\begin{array}{l}\text { Other } \\
\text { films }\end{array}$} & Yes & 34 \\
\hline & No & 74 \\
\hline \multirow{2}{*}{$\begin{array}{l}\text { Who } \\
\text { mentions } \\
\text { the film? }\end{array}$} & Author & 229 \\
\hline & Other & 7 \\
\hline \multirow{2}{*}{$\begin{array}{c}\text { Formal } \\
\text { citation style }\end{array}$} & Yes & 4 \\
\hline & No & 104 \\
\hline
\end{tabular}

biotechnology referenced in movies such as "Jurassic Park" and "The Island." The podcast was offered to students in my lecture courses as an optional exercise to listen to outside of class." [22].

- Dissemination, opinion formation: it refers to the papers in which a film reference is used to disseminate an idea, to form an opinion or to convince the reader in a wider communication context, not belonging to formal education.

E.g.

"The release of Jurassic Park in 1993, a movie based on Michael Crichton's best-selling novel of the same name, became the world's highest-grossing movie to that point and provided a cross-cultural metaphor for public discussion of ancient DNA research." [5]

- Predictive elements: when a reference to a film is made to show elements predicting scientific developments that actually occurred after the release of the film or that still have to occur.

E.g.

"The attraction of the synopsis of journalistic and entertaining forms of public communication is also shown when a German newspaper publishes an article on the deciphering of the human genome, while already three years before in the feature film GATTACA (1997) — or even earlier in Aldous Huxley's book Brave New World (1932) - it was demonstrated what a society in which genes determine a person's value could look like." [6]

- As an example of a process or a concept: when a film reference is made to exemplify or to stress something that is being explained in the paper. 
E.g.

"Even with space travel successes in the 1960s, culminating with the moon landing in 1969, scientists still considered fictional films as a useful vehicle for popularising space ventures. 2001: A Space Odyssey was a classic example of cinema creating expectations for space travel, as well as other technologies, with more than 65 private companies, government agencies, universities and research institutions providing free advice and material objects for the opportunity of shaping technological visions in a highly anticipated film about the future." [14]

- Study subject: when a film reference is part of the data that the paper presents as a study subject.

E.g.

"Audiences could see with their own eyes 'real' people effortlessly interacting with these futuristic computer technologies in The Lawnmower Man, Virtuosity, Minority Report, Paycheck, Iron Man and other computer-based films. Underkoffler, in fact, felt that the potential of cinema for technological development should be brought into the scientific and design community. After Minority Report Underkoffler and Production Designer Alex McDowell helped to form an organisation called MATTER Art and Science, whose objective is to transfer the creative methods of cinema into scientific and engineering work". [14]

- In support of science: when a film reference is made to highlight a positive aspect of scientific development, concerning the film itself or the paper argument.

E.g.

"Admittedly, we should recognise that incremental scientific advances could eventually lead to significant changes in human experience. Furthermore, developments in biomedical research are unpredictable. But humans are capable of adapting to changing circumstances. If life expectancy rates continue to increase gradually in developed nations, pension plans, retirement ages and social welfare schemes can be all adjusted to acknowledge evolving circumstances. Social institutions, political systems and patterns of family life are adaptable. We should not let exaggerated rhetoric and futuristic portrayals of the bleakest dystopian scenes deter us from acknowledging the human capacity to reconfigure social institutions in a creative, fair and sensible fashion. Contemporary research seeking to understand better the biology of aging need not culminate in a Blade Runner world". [24]

- Negative element: when a film reference is made to highlight a negative aspect of scientific development, concerning the film itself or the paper argument.

E.g.

"In atomic cinema, the apocalypse is harnessed directly to the power of the nation-state, promoting a perverse kind of nation-building through images of collective sacrifice and death. For 60 years now Hollywood has produced big 
budget, special effects-driven stories about nuclear warfare (often allegorised), playing off of the Civil Defense promises and nuclear fears of the Cold War state. The cinematic destruction of New York - often codified in a ruined Statue of Liberty - has become an almost annual project in Hollywood and one that provides a precise genealogy of US nuclear fears, from When Worlds Collide (1951) to The Planet of the Apes (1968) (see figure 6) to The Day After Tomorrow (2004). The producers of The Day After Tomorrow are particularly attuned to this filmic register, having established their careers by revisiting Cold War atomic cinema (in Independence Day and Godzilla).” [21]

It can be noted that almost one fourth of the references are used as an example to stress a scientific concept or process (24\%). A higher percentage of papers refer to sci-fi films aiming to form or disseminate an opinion (32\%). The reference to predictive elements was also significant in an wide portion of the articles (16\%). It should also be noted that, differently from what occurs with the studies on the scientist' stereotypes, in which negative versions of people dealing with science are usually found, there are very few film references in the papers aiming to criticise science (3\%), whereas those used to support science or praise it account for $10 \%$ of the references and, taking the predictive elements as a positive characteristic, they reach $25 \%$ of the references (Figure 2).

By analysing those characteristics of the references for each of the shortlisted films, it appears that only The Planet of the Apes is mentioned in the title of a scientific paper, whereas The Andromeda Strain, Frankenstein and Matrix are used as a resource in the introduction. Only in two cases they are not mentioned in the text by the author: for The Andromeda Strain the reference is made by quoting a newspaper article, whereas for Minority Report the reference is made through a remark by the film producer. This aspect is interesting because the purpose of the film reference may be different when it is not made by the author.

With regard to the purpose for the reference, Jurassic Park is the film receiving more references in the full text and, in general, this is done aiming to disseminate or form opinions (category b) (Figure 3).

\subsection{Discussion}

One of the main purposes of this work was to analyse the relation between sci-fi cinema and academic texts. We started from the hypothesis that sci-fi cinema has an influence on the academic world and this reflects in the publications. To find evidence of this, we analysed the references to films belonging to this genre in the papers.

Traditionally, the quantitative analysis of the scientific literature on a specific subject - carried out mainly by studying its formal characteristics and measuring its evolution, impact or visibility - belongs to the field of bibliometrics. However, the investigations have allowed us to find that there are not any previous studies based on bibliometric methods that analyse the citations of science fiction films in the papers. Our research in WoS led us to identify a corpus of 400 general papers (found using the terms film 


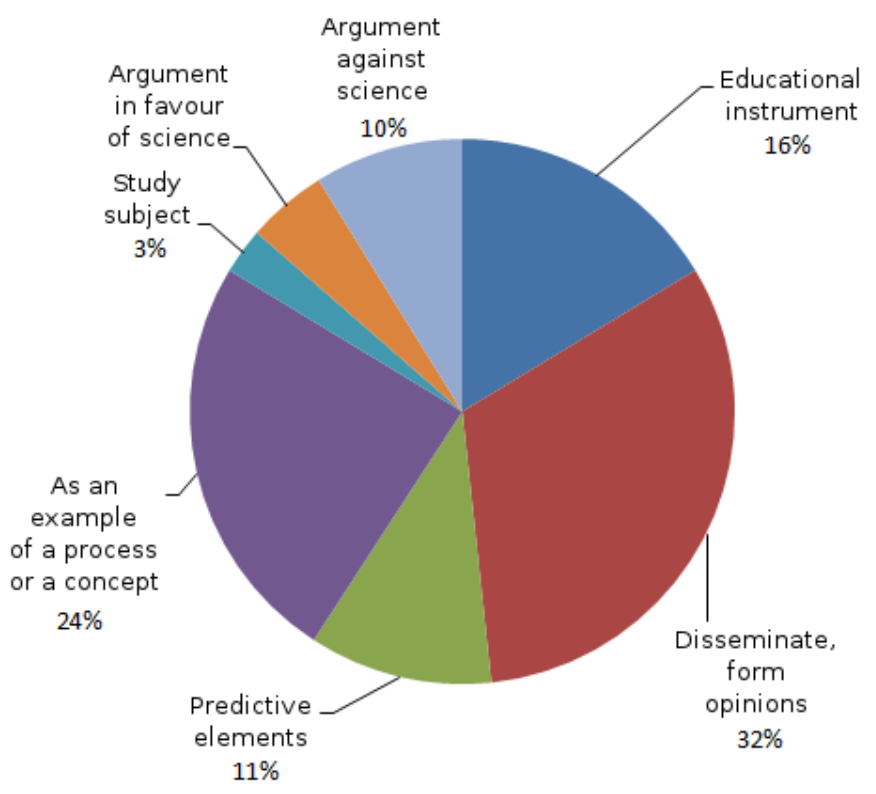

Figure 2. Purposes of film references in the texts (aggregate data).

+ science fiction), plus 300 articles specifically dealing with the 20 films selected. In addition, 108 documents were collected from four sources analysed in their full texts (BioOne, Cell, PUS, SSS), for a total number of papers exceeding 800. On the basis of the method adopted for our research, we analysed only a portion of such a vast corpus, but it can certainly be noted that there is a considerable volume of documents in this field, even though it is hard to estimate the total number of papers dealing with science fiction cinema. In addition, we had to acknowledge that this universe is much more significant than what the research methods adopted could reveal. Therefore, further research in this field may involve widening the selection of films or devising more powerful strategies to gain access to the existing texts.

In the same perspective, the importance of publications dealing with different aspects of cinema was revealed by a recent study [2]. The text, which analyses papers published in the journal Public Understanding of Science over 20 years, shows that the number of works that analyse films or TV programmes has increased significantly. Whereas in the period 1992-2001 this genre accounted for about $2 \%$ of the publications in the journal, in the period 2002-2010 it reached over 7\%, becoming the category seeing the higher increase over time.

The lack of previous studies focusing on the way science fiction films are used to transfer, communicate, build or criticise specific scientific knowledge may be due to two reasons: perhaps this corpus of papers is not relevant, or it may have not been perceived as such. We have shown that there is a wide group of papers. The fact that it has not been perceived as relevant may be due to two significant issues that are worth discussing here. 


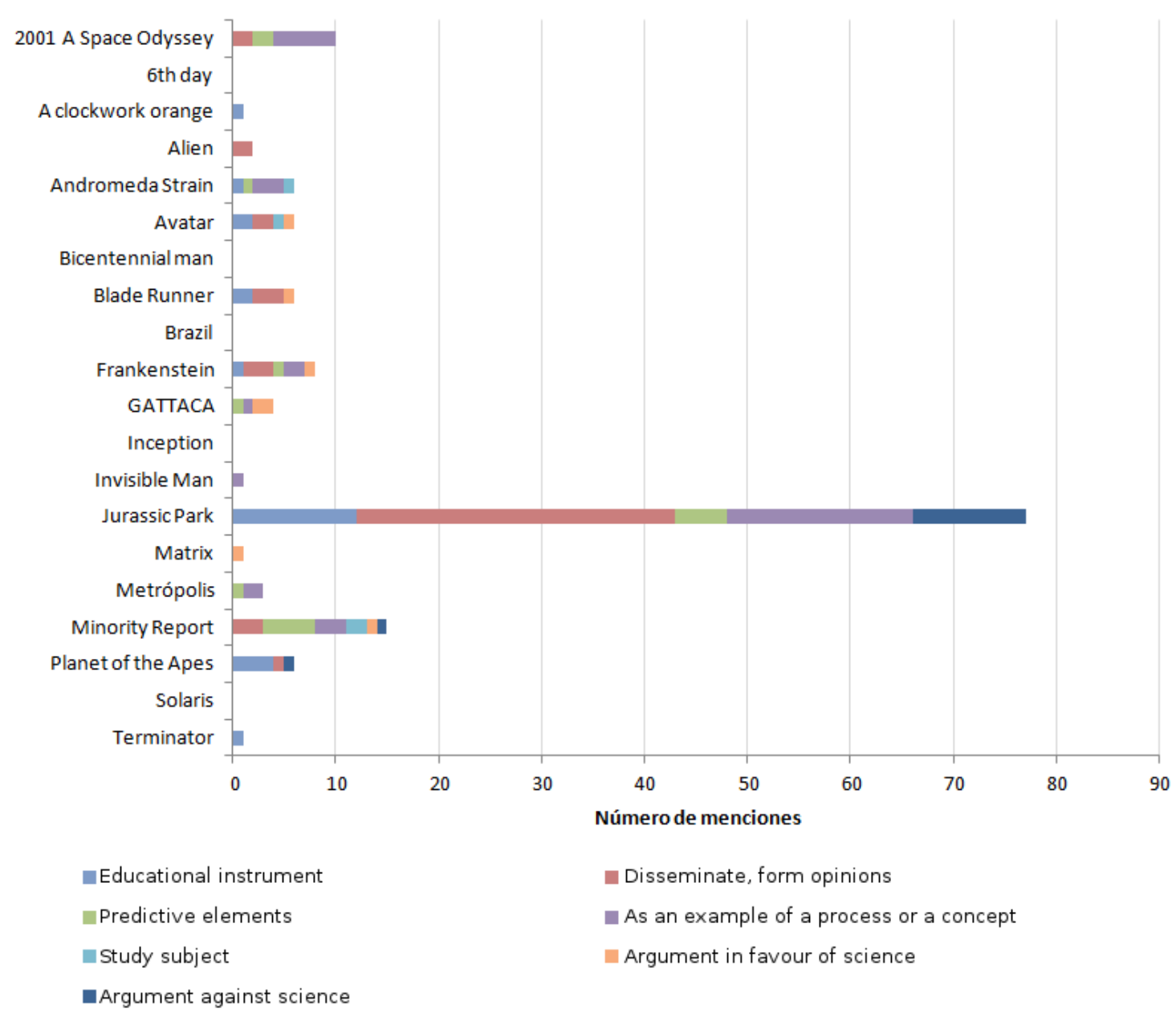

Figure 3. Purpose for each film.

The first has to do with the general aspects of cinema as a carrier of knowledge, whereas the second concerns science fiction in particular.

In order to analyse the first issue, one of the hypothesis is related to the value that pictures have been acquiring as carriers of knowledge. As Latour already noted [18], scientific inscription and writing devices have a powerful ability to convey knowledge that is associated to a powerful ability to "involve". Inscription and writing devices can be categorised into those that generate encoded inscriptions (letters, numbers, certain images that are also encoded, such as protein representations) and those that generate images that are not encoded, as photocameras and camcorders [17]. Another classification can be established according to the place or the person responsible for the inscription. An inscription generated by an inscriber manipulated by a scientist is not the same thing as an inscription coming from outside the scientific production space. The relative values of these different types of inscriptions have not been the subject of in-depth studies, although it is evident that their involvement abilities are not equivalent. In this sense, films have turned into 
complex inscriptions and the participation of renowned scientists in their production process also makes their analysis complex, since their value as a communication support of the credibility of knowledge has been placed under scrutiny. Their ability to enrol different types of players is diverse. A film like Jurassic Park can easily enrol allies - to use Latour's terminology: general public, politicians, investors in palaeontology areas and a certain type of scientists. However, those who do not subscribe to the theories or disagree with the disputes represented in the film (whether dinosaurs were birds or reptiles) have clearly expressed themselves against it. In this sense, films that involve scientific advisors move closer to an "academic" inscriber's role and this is an additional argument to consider their increased presence in scientific literature.

The second issue that may contribute to explain the lack of studies on the cinema in science is related to the much debated role that science fiction has played in the dissemination and communication of scientific concepts. Although it was a genre overlooked by the academic world, it has gained room in the past few decades. In this sense, as Barceló has argued, science fiction has managed to be included in the curricula of Anglo-Saxon high schools and colleges and has also been incorporated into the teaching world, with varying degrees across disciplines. This explains the growing collection of academic papers and books that deal with the themes of science fiction, as well as the emergence of academic journals specialising in this genre [1].

Another interesting issue that has emerged from our work is the definition of when a film is more or less referenced and why. In this regard, we have observed that commercial success does not play a role in the citation of a film in scientific literature. In a first hypothesis, this observation would be justified by the themes dealt with: most of the references are about the films that deal with subjects that are key to science, education or society. However, this hypothesis does not seem to be enough. Some authors argue that Jurassic Park is a film that saw the participation from many scientific advisors and this provided it with a scientific and technical adequacy that underlies its commercial success [12,15]. The same applies to 2001: A Space Odyssey, perhaps the film that shows the best adequacy in its theory, technologies and narration. Unfortunately, there are no similar data for all the films considered able to give insight on whether this adequacy, based on scientific advice, is actually the factor that has lead to the surge in citations within academic literature.

Another factor to take into account is the explicit presence of scientific disputes. For example, in the case of Jurassic Park, the reference to the above-mentioned theory that relates dinosaurs to birds through a common ancestor or the possibility of using amber to retrieve ancient DNA are elements that make this film one of the most referenced in academic literature. The same occurs with predictive elements.

\section{Conclusions}

The information gathered has allowed us to demonstrate that Jurassic Park and 2001: A Space Odyssey are two of the three films that show the highest degree of interdisciplinarity 
in terms of journals publishing papers that cite them. This could be a hint of the direction to follow in the future search for data explaining the greater presence of a film in academic literature. As previously mentioned, there are two elements of these films that promote their use: scientific advice and the presence of scientific disputes in their arguments.

There are different usages of films that may be detected and categorised through the analysis of the content of papers. Through our analysis, it was possible to identify the purposes for the citation, which include the dissemination/formation of an opinion coming in first place, and the use of a film as an example of a process or as an educational instrument coming respectively in second and third place.

As we see, the pedagogical character of a film citation is quite widespread, but there are nuances to it. In this regard, we have found that the existence of elements that clearly belong to formal education curricula is quite an evident indicator of the larger use of a specific film in academic literature. This is the case of Jurassic Park, Blade Runner or The Planet of the Apes.

A further element to consider is the audience the papers are addressed to. In this respect, it is evident that the category "dissemination/formation of an opinion" does not relate to the intention of explaining a concept to an audience, but of convincing readers that such idea is valid. It is a rhetorical process aimed to "enrol" the readers (other scientists) so that they can side with the argument of the paper.

By contrast, the category "educational instrument" comes from academic journals oriented towards the teaching of biology, whose readers are biology teachers. There, the pedagogical emphasis of the film is bigger.

\section{A List of the journals with publications on the shortlisted science fiction films (se- lected papers)}

\begin{tabular}{|l|l|r|}
\hline Discipline & Journal & Papers \# \\
\hline Humanities multidiscplinary & $\begin{array}{l}\text { TLS-THE TIMES LITERARY SUPPLE- } \\
\text { MENT }\end{array}$ & 5 \\
\hline Economics/ Planning development & FUTURES & 4 \\
\hline Information Sciences \& Library & LIBRARY JOURNAL & 3 \\
\hline $\begin{array}{l}\text { Cultural studies /Humanities multidis- } \\
\text { plinar }\end{array}$ & JOURNAL OF POPULAR CULTURE & 3 \\
\hline Humanities multidiscplinary & NEW YORK REVIEW OF BOOKS & 2 \\
\hline Architecture & ARCHITECTURAL DESIGN & 2 \\
\hline $\begin{array}{l}\text { Communication } \\
\text { History }\end{array}$ & \begin{tabular}{l} 
CRITICAL STUDIES IN MASS COM- \\
\hline $\begin{array}{l}\text { Mechanical Engineering / Aerospace en- } \\
\text { gineering /automatisation and control sys- } \\
\text { tems }\end{array}$
\end{tabular} & SISTORY TODAY \\
\hline
\end{tabular}




\begin{tabular}{|c|c|c|}
\hline Discipline & Journal & Papers \# \\
\hline Computer Sci. Cybernetics / Computer & 3RD INT CONF ON CYBERNETICS & 1 \\
\hline Sci. information systems / Comp Sci. & AND INFORMATION TECHNOLO- & \\
\hline interdisciplinary applications / Computer & GIES, SYSTEMS, AND APPLICAT/4TH & \\
\hline Sci. theory and methods & INT CONF ON COMPUTING, COM- & \\
\hline & MUNICATIONS AND CONTROL & \\
\hline & & \\
\hline Law & 6th LatCrit Symposium & 1 \\
\hline Computer Sci. Sottware Engineering & ACM TRANSACTIONS ON GRAPHICS & 1 \\
\hline Aerospacial engineering & AEROSPACE & 1 \\
\hline Multidisciplinary sciences & AMERICAN SCIENTIST & 1 \\
\hline Humanities multidiscplinary & $\begin{array}{l}\text { ANGELAKI-JOURNAL OF THE THEO- } \\
\text { RETICAL HUMANITIES }\end{array}$ & 1 \\
\hline Medicine General Internal & ANNALS OF INTERNAL MEDICINE & 1 \\
\hline Classics & ARETHUSA & 1 \\
\hline $\begin{array}{l}\text { Thermodynamics / Engineering mechani- } \\
\text { cal /Constructing building technology }\end{array}$ & ASHRAE JOURNAL & 1 \\
\hline Pshychiatry & $\begin{array}{l}\text { AUSTRALIAN AND NEW ZEALAND } \\
\text { JOURNAL OF PSYCHIATRY }\end{array}$ & 1 \\
\hline Biology & BIOSCIENCE & 1 \\
\hline Information Sciences \& Library & $\begin{array}{l}\text { BULLETIN OF THE MEDICAL LI- } \\
\text { BRARY ASSOCIATION }\end{array}$ & 1 \\
\hline Optics & CHINESE OPTICS LETTERS & 1 \\
\hline Polítical Sciences / Social Issues & COMMENTARY & 1 \\
\hline $\begin{array}{l}\text { Computer Sci. Artificial Intelligence / } \\
\text { Computer Sci. software engineering }\end{array}$ & COMPUTER GRAPHICS WORLD & 1 \\
\hline Criminology, penology / Sociology & CRIME MEDIA CULTURE & 1 \\
\hline Computer Sci. Cybernetics / Computer & CRITICAL TECHNOLOGIES FOR THE & 1 \\
\hline $\begin{array}{l}\text { Sci. information systems / Comp SCI } \\
\text { interdisciplinary applications / Computer } \\
\text { Sci. theory and methods }\end{array}$ & FUTURE OF COMPUTING & \\
\hline Biology / Molecular biology & CURRENT BIOLOGY & 1 \\
\hline Literary theory criticism & DEUTSCHE VIERTELJAHRSSCHRIFT & 1 \\
\hline & $\begin{array}{l}\text { FUR LITERATURWISSENSCHAFT } \\
\text { UND GEISTESGESCHICHTE }\end{array}$ & \\
\hline Astronomy and Astrophysics /Geoscience & EARTH MOON AND PLANETS & 1 \\
\hline Education Educational Research & ENGLISH JOURNAL & 1 \\
\hline Urban studies & EURE-REVISTA $\quad$ LATINOAMERI- & 1 \\
\hline & $\begin{array}{l}\text { CANA DE ESTUDIOS URBANO } \\
\text { REGIONALES }\end{array}$ & \\
\hline Imaging Sciences Photographic / Optics & EXTRAPOLATION & 1 \\
\hline Social issues & FUTURIST & 1 \\
\hline $\begin{array}{l}\text { Computer Sci. Artificial Intelligence / } \\
\text { Imaging Sci. Photographic Technology }\end{array}$ & $\begin{array}{l}\text { GRAPP 2009: PROCEEDINGS OF THE } \\
\text { FOURTH INTERNATIONAL CONFER- } \\
\text { ENCE ON COMPUTER GRAPHICS } \\
\text { THEORY AND APPLICATIONS }\end{array}$ & 1 \\
\hline Humanities multidiscplinary & GREY ROOM & 1 \\
\hline History & HISTOIRE & 1 \\
\hline History & HISTORIA & 1 \\
\hline
\end{tabular}




\begin{tabular}{|c|c|c|}
\hline Discipline & Journal & Papers \# \\
\hline History & HISTORISCHE ZEITSCHRIFT & 1 \\
\hline Developmental Psychology & HUMAN DEVELOPMENT & 1 \\
\hline $\begin{array}{l}\text { Astronomy and Astrophysics /Geoscience } \\
\text { / Biology }\end{array}$ & $\begin{array}{l}\text { INTERNATIONAL JOURNAL OF AS- } \\
\text { TROBIOLOGY }\end{array}$ & 1 \\
\hline Aerospacial engineering & $\begin{array}{l}\text { INTERNATIONAL SPACE STATION: } \\
\text { THE NEXT SPACE MARKETPLACE }\end{array}$ & 1 \\
\hline $\begin{array}{l}\text { Engineering industrial / Engineering mul- } \\
\text { tidisciplinary / Multidisciplinary Sciences } \\
\text { / Social Issues }\end{array}$ & $\begin{array}{l}\text { ISSUES IN SCIENCE AND TECHNOL- } \\
\text { OGY }\end{array}$ & 1 \\
\hline $\begin{array}{l}\text { Engineering electrical electronic /Imaging } \\
\text { Photographic technology /Optics }\end{array}$ & JOURNAL OF ELECTRONIC IMAGING & 1 \\
\hline Communication / Economics & JOURNAL OF MEDIA ECONOMICS & 1 \\
\hline Aerospace engineering & $\begin{array}{llll}\text { JOURNAL } & \text { OF } & \text { SPACECRAFT } & \text { AND } \\
\text { ROCKETS } & & & \\
\end{array}$ & 1 \\
\hline Humanities multidiscplinary & $\begin{array}{l}\text { JUNG JOURNAL-CULTURE \& PSY- } \\
\text { CHE }\end{array}$ & 1 \\
\hline Architecture & LANDSCAPE ARCHITECTURE & 1 \\
\hline Medicine Research Experimental & M S-MEDECINE SCIENCES & 1 \\
\hline Cultural Studies & MEMORY STUDIES & 1 \\
\hline Humanities multidiscplinary & MODERNISM-MODERNITY & 1 \\
\hline Bidiversity conservation / Ecology & NATURAL HISTORY & 1 \\
\hline Multidisciplinary Sci. & NATURE & 1 \\
\hline $\begin{array}{l}\text { Ethics/ Social Sci Biomedical / Medical } \\
\text { ethics }\end{array}$ & NEUROETHICS & 1 \\
\hline $\begin{array}{l}\text { Economics / International relations / Polit- } \\
\text { ical Sciences }\end{array}$ & NEW POLITICAL ECONOMY & 1 \\
\hline Humanities multidiscplinary & POSTMODERN CULTURE & 1 \\
\hline $\begin{array}{l}\text { Engineering electric and electronics / Op- } \\
\text { tics / Material Sci Composites / Polymer } \\
\text { Sciences }\end{array}$ & $\begin{array}{l}\text { PROCEEDINGS OF THE SOCIETY OF } \\
\text { PHOTO-OPTICAL INSTRUMENTA- } \\
\text { TION ENGINEERS (SPIE) }\end{array}$ & 1 \\
\hline $\begin{array}{l}\text { Criminology, penology / Law / Psychology } \\
\text { multidisciplinary }\end{array}$ & PSYCHOLOGY CRIME \& LAW & 1 \\
\hline Psichology clinical & PSYCHOTHERAPY & 1 \\
\hline Philosophy & $\begin{array}{l}\text { REVUE DE METAPHYSIQUE ET DE } \\
\text { MORALE }\end{array}$ & 1 \\
\hline Humanities multidiscplinary & $\begin{array}{llll}\text { REVUE } & \text { FRANCAISE } & \text { D } & \text { ETUDES } \\
\text { AMERICAINES } & & \\
\end{array}$ & 1 \\
\hline History & RUSSIAN REVIEW & 1 \\
\hline Multidisciplinary Sci. & SCIENTIFIC AMERICAN & 1 \\
\hline Religion & Semeia & 1 \\
\hline Humanities multidiscplinary & SEMIOTICA & 1 \\
\hline $\begin{array}{l}\text { Computer Sci. Cybernetics / Computer } \\
\text { Sci. information systems / Comp Sci. in- } \\
\text { terdisciplinary applications / Computer Sci } \\
\text { theory and methods }\end{array}$ & $\begin{array}{l}\text { SIGCSE 12: PROCEEDINGS OF THE } \\
\text { 43RD ACM TECHNICAL SYMPOSIUM } \\
\text { ON COMPUTER SCIENCE EDUCA- } \\
\text { TION }\end{array}$ & \\
\hline $\begin{array}{l}\text { Engineering electrical electronic /Imaging } \\
\text { Photographic technology / Instruments in- } \\
\text { strumentation /telecommunications }\end{array}$ & SMPTE JOURNAL & 1 \\
\hline
\end{tabular}




\begin{tabular}{|l|l|r|}
\hline Discipline & Journal & Papers \# \\
\hline $\begin{array}{l}\text { Architecture / Planning development / Ur- } \\
\text { ban studies }\end{array}$ & $\begin{array}{l}\text { Space Syntax 5th International Sympo- } \\
\text { sium }\end{array}$ & 1 \\
\hline Aerospacial engineering & $\begin{array}{l}\text { SPACE TECHNOLOGY AND APPLICA- } \\
\text { TIONS INTERNATIONAL FORUM }\end{array}$ & 1 \\
\hline Philosophy & SYNTHESIS PHILOSOPHICA & 1 \\
\hline Communication & TECHNICAL COMMUNICATION & 1 \\
\hline History and Philosophy of sciences & TECHNOLOGY AND CULTURE & 1 \\
\hline Imaging Sciences Photographic / Optics & $\begin{array}{l}\text { THREE-DIMENSIONAL IMAGING, VI- } \\
\text { SUALIZATION, AND DISPLAY }\end{array}$ \\
\hline Veterinary & VETERINARY ECONOMICS & 1 \\
\hline Humanities multidisciplinary & ZEITSCHRIFT FUR SEMIOTIK & 1 \\
\hline
\end{tabular}

\section{References}

[1] M. Barceló (2003), “Ciencia y ciencia ficción”, Quark 28-29, http://quark.prbb.org/28-29/028097.htm.

[2] M.W. Bauer and S. Howard (2012), "Public Understanding of Science - a peer-review journal for turbulent times", Pub. Underst. Sci. 21(3): 258-267, DOI: 10.1177/0963662512443407.

[3] M.W. Bauer and S. Howard (2013), "Public Understanding of Science: compiled bibliography, 1992-2011”, Pub. Underst. Sci., http://pus.sagepub.com/site/misc/PUS_book_v6_AG.pdf.

[4] A. Bergvall (2012), "Apocalyptic Imagery in Fritz Lang's Metropolis", Literature-film quarterly 40(4): 246-257.

[5] A. Fletcher (2010), “Genuine fakes”, Polit. Life Sci. 29(1): 48-60, DOI: 10.2990/29_1_48.

[6] A. Görke, and G. Ruhrmann (2003), "Public Communication between Facts and Fictions: On the Construction of Genetic Risk", Pub. Underst. Sci. 12(3): 229-241, DOI: $10.1177 / 0963662503123002$.

[7] R. Haynes (2003), "From Alchemy to Artificial Intelligence: Stereotypes of the Scientist in Western Literature", Pub. Underst. Sci. 12(3): 243-253, DOI: 10.1177/0963662503123003.

[8] D. Jalufka and C. Koeberl (1999), "Moonstruck: How Realistic Is The Moon Depicted In Classic Science Fiction Films?”, Earth, Moon, and Planets 85-86(0) 179-200, DOI: $10.1023 / \mathrm{A}: 1017015931543$.

[9] K.M. Johnson (1979), "Ebola Virus and Hemorrhagic Fever: Andromeda Strain or Localized Pathogen?”, Ann. Intern. Med. 91(1): 117-119.

[10] C. Kelty and H. Landecker (2004), “A Theory of Animation: Cells, L-systems, and Film”, Grey Room 17: 30-63, DOI: 10.1162/1526381042464536.

[11] D.A. Kirby (2000), "The New Eugenics in Cinema: Genetic Determinism and Gene Therapy in GATTACA”, Science Fiction Studies 27(2): 193.

[12] D.A. Kirby (2003), "Science Consultants, Fictional Films, and Scientific Practice”, Soc. Stud. Sci. 33(2): 231-268, DOI: 10.1177/03063127030332015.

[13] D.A. Kirby (2003), "Scientists on the Set: Science Consultants and the Communication of Science in Visual Fiction”, Pub. Underst. Sci. 12: 261-287.

[14] D.A. Kirby (2010), “The Future is Now: Diegetic Prototypes and the Role of popular Films in Generating Real-world Technological Development”, Soc. Stud. Sci. 40(1): 41-70. 
[15] D.A. Kirby (2011), Lab Coats In Hollywood. Science, Scientists, and Cinema, MIT Press, Cambridge, MA, U.S.A. .

[16] H. Landecker (2006), "Microcinematography and the History of Science and Film", Isis 97(1): 121-132, DOI: 10.1086/501105.

[17] B. Latour (1990), "Drawing Things Together", in M. Lynch and S. Woolgar eds., Representation in Scientific Practice, MIT University Press, U.S.A.

[18] B. Latour and S. Woolgar (1979), Laboratory Life. The Social Construction of Scientific Facts, SAGE, Beverly Hills, U.S.A. .

[19] L. Levin and P. Kreimer (2011), "Las dimensiones sociales de la ciencia en el cine", in B. Jefferson de Oliveira and C. Carrillo Trueba eds., Ciência no Cinema. Uma olhada latino-americana, Argumentum Editora y Scientia, Mina Gerais.

[20] M. Long and J. Steinke (1996), "The thrill of everyday science: images of science and scientists on children's educational science programmes in the United States”, Pub. Underst. Sci. 5(2): 101-119, DOI: $10.1088 / 0963-6625 / 5 / 2 / 002$.

[21] J. Masco (2010), "Bad Weather: On Planetary Crisis”, Soc. Stud. Sci. 40(1): 7-40, DOI: $10.1177 / 0306312709341598$.

[22] J. De. Souza-Hart (2011), "Creative Ideas for Biology Podcasts: The Immune System as an Example”, Am. Biol. Teach. 73(3): 171-175, DOI: 10.1525/abt.2011.73.3.9.

[23] D. Suvin (1984), Metamorfosis de la ciencia ficción, FCE, México.

[24] L. Turner (2004), "Biotechnology, bioethics and anti-aging interventions", Trends Biotechnol. 22(5): 219-221, DOI: 10.1016/j.tibtech.2004.03.008.

[25] P. Weingart, C. Muhl and P. Pansegrau (2003), "Of Power Maniacs and Unethical Geniuses: Science and Scientists in Fiction Film”, Pub. Underst. Sci. 12: 279-287.

[26] P. Yeh and C. Gu (2013), "3D displays: toward holographic video displays of 3D images”, Chin. Opt. Lett. 11(1): 10901, http://col.osa.org/abstract.cfm?URI=col-11-1-010901.

\section{Authors}

Luciano Guillermo Levin is a researcher at the Centro de Ciencia, Tecnología y Sociedad (CCTS) of the Universidad Maimónides, Buenos Aires, Argentina. E-mail: lucianolevon@gmail.com.

Daniela De Filippo is a researcher at the Laboratorio de Estudios Métricos de la Información (LEMI) of the Universidad Carlos II of Madrid. E-mail: dfilippo@bib.uc3m.es.

How to CiTE: L.G. Levin and D. De Filippo, "Films and Science: quantification and analysis of the use of Science Fiction films in scientific papers", JCOM 13(03)(2014)A07. 